International Journal of Instruction e-ISSN: 1308-1470 • www.e-iji.net

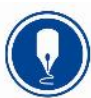

January $2019 \bullet$ Vol.12, No.1

p-ISSN: 1694-609X

pp. $1567-1584$

Received: 28/05/2018

Revision: 15/10/2018

Accepted: 20/10/2018

OnlineFirst: 17/12/2018

\title{
An Analysis of Quality Assurance Key Performance Indicators in Research in Ugandan Universities
}

\section{Matovu Musa}

$\mathrm{PhD}$, Islamic University in Uganda, Uganda, matovumousa@yahoo.com \& m.matovu@iuiu.ac.ug

In a university, research is used to generate new knowledge and also increases the visibility of the university. The quality of research undertaken by the university is important in defining the nature of the university and its ranking nationally, regionally, and internationally. In universities, for research to be vibrant and quality-oriented, it should be based on achievable Quality Assurance Key Performance Indicators (QA_KPIs). This paper analyses QA_KPIs used to guide researches at the Islamic University in Uganda. The objectives of this study included (a) to understand the roles of QA_KPIs in research at Islamic University in Uganda (IUIU), (b) to examine the differences in staff perceptions on QA_KPIs in research at Islamic University in Uganda, and (c) to examine the relationship between QA_KPIs' variables used in maintaining quality in research at the Islamic University in Uganda. Results of descriptive statistics highlight that 154 majority of staff agreed that QA_KPIs have a role to play in ensuring the quality of research at the Islamic University in Uganda. It was observed that there was a statistically mean difference in staff perceptions as regards QA_KPIs in the academic qualifications. It was also observed that there are relationships between QA_KPI variables on the quality of research undertaken at Islamic University in Uganda.

Keywords: quality assurance, key performance indicators, research, case study, Uganda

\section{INTRODUCTION}

According to various studies, quality assurance is defined as ensuring stakeholders that the education offered by the university is "fit for purpose" (Elassy, 2015; Hénard \& Roseveare, 2012; Mbabazi, 2013; Salilul \& Shahadat, 2016;). Quality assurance is also defined as a collection of policies, procedures, systems, and practices designed to achieve, maintain, and enhance quality of education offered (Matovu, 2017; Sanga \& Ahn, 2014; Williams, 2016). Quality assurance should be managed from both the internal and external processes that are highly controlled by known procedures to all stakeholders (Manghani, 2011; Sanga \& Ahn, 2014). Quality assurance might require heavy investment of funds so as to acquire the best technology, equipment, and skills to

Citation: Musa, M. (2019). An Analysis of Quality Assurance Key Performance Indicators in Research in Ugandan Universities. International Journal of Instruction, 12(1), 1567-1584. https://doi.org/10.29333/iji.2019.121100a 
take the university to another level (Kane, Palmer, Phillips, Kiron \& Buckley, 2016; Williams, 2016). Quality Assurance is one of the core processes used by higher education institutes for quality management of teaching, community service, and research (ESG, 2015; Kwadwo \& Addaney, 2016; Matovu, 2017; Michaela, 2018; VanVught \& Westerheijden, 1994). Quality assurance in research relies on Key Performance Indicators (KPIs) to provide guidelines for quality research that is later reflected in the total institutional performance and growth (Harvey \& Green, 1993; Matovu, 2017; Sanga \& Ahn, 2014). This paper suggests that universities should ensure that QA_KPIs are implemented by universities. These would help universities to undertake quality research, publish, patent, prototype, and also make products out of generated knowledge.

\section{LITERATURE REVIEW}

Key performance indicators are measurable values or metrics that are used to evaluate how effectively a university or an organization achieves its goals (Eckerson, 2009; Lee, Park \& Kim, 2013; Masayna, Koronios \& Gendron, ND; Meier, Lagemann, Morlock \& Rathmann, 2013). KPIs help to communicate the actual targets, drive improvement by facts, help prioritizing improvement activities, make continued quality check for universities and connects students to institutional processes (Ballard, 2013). KPIs are developed within the universities' visions, missions, objectives/ goals, strategic plans, values, etc. Research KPIs should be able to guide generation of quality oriented, efficient and timely new knowledge useful to all stakeholders (ISESCO, 2016). KPIs are usually selected according to the SMART concept (Specific, Measurable, Attainable, Relevant, and Time-bound). In order for KPIs to be implemented, there should clearly defined guides and criteria on which factual based decisions are made. Key performance indicators in universities have been related to the improvement of the following aspects; (a) teaching (b) research, (c) communality engagement, and (d) international outlook (Brockerhoff, Huisman \& Laufer, 2015; Gueorguiev, 2017; Piela, 2017). There are several benefits that higher education institutions might accrue as a result of QA_KPIs for research being in place. According to literature, QA_KPIs help universities in attaining the desired goals, are a source point to compare qualifications, a source of comparison of graduates, and set transparent mechanisms in controlling quality and standards (Asian Pacific Economic Cooperation [APEC], 2011; Ballard, 2013; Karen, 2012).

In higher education institutions it is very important to have QA_KPIs in place. These help in ensuring that all qualification and academic standards are in place for the institution to function as expected by all its stakeholders (APEC, 2011; Kis, 2005; Manghani, 2011; Paintsil, 2016). The standards that might be involved in ensuring that quality measures are adhered to include; (a) institutional quality assurance standards, (b) national quality assurance standards, (c) regional quality assurance standards, and (d) international quality assurance standards (Inter-University Council for East Africa [IUCEA], 2010; IUCEA, 2011; IUCEA, ND; National Council for Higher Education [NCHE], 2009; NCHE, 2011; Nkunya, 2011; Nkunya \& Joseph, ND). KPIs might require improvement after a given period of time to match the changes of the time. 


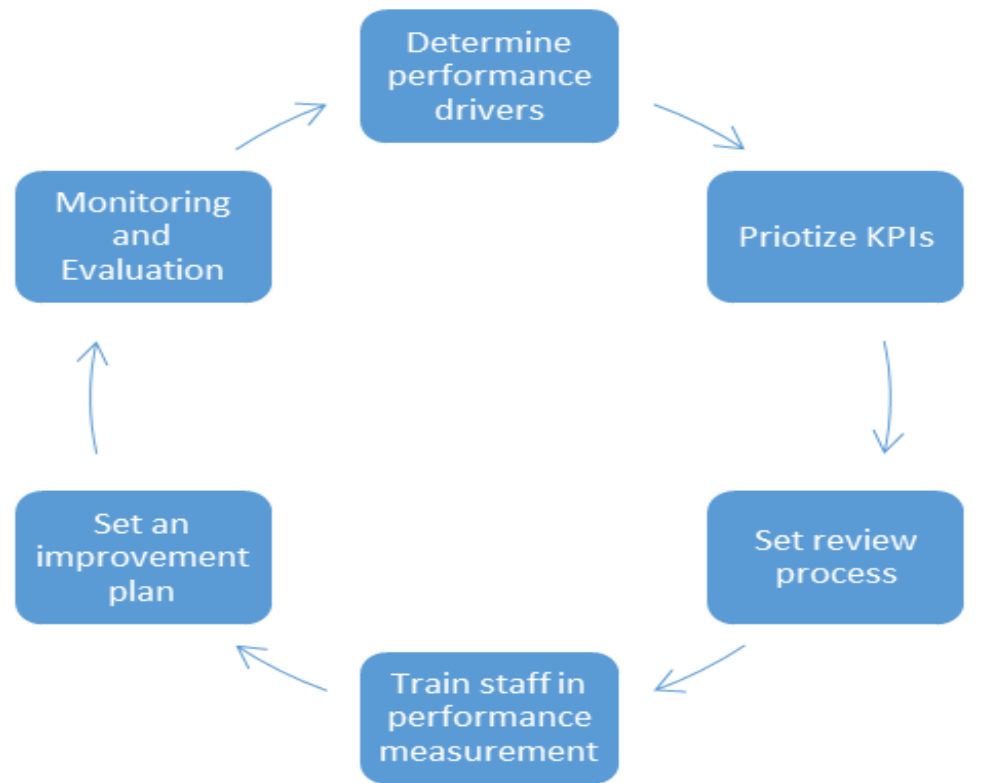

Figure 1

Continuous Improvement Cycle of KPIs

\section{Best practices in ensuring QA_KPIs in research}

Universities should not only look at having key performance indicators in place but they should also ensure that they are functional and serve their goal (Ballard, 2013; Owino, Ogachi \& Olel, 2011; Piela, 2017; Wang, 2010). Universities should have policies and procedures that manage the implementation of quality assurance key performance indicators to bring out proper results they are designed to implement. There should be measures of how quality research should be undertaken by staff and students, and in which direction (Henard \& Leprince-Ringuet, 2008; Coe, Aloisi, Higgins \& Elliot, 2014). The research policies and practices should be specific for all other aspects of the university function. In the same vain, there should be facilities that are directed towards supporting research activities in order to tally with QA_KPIs which are being measured against. The facilities put into play might include technology, libraries, laboratories, link to the cyber world, and mechanisms to support the provided technology (Hennessy at al., 2010; Council on Higher Education, 2016). With quality assurance in research, there should be increased funding to support research activities. Having enough funds to do quality research leads to meeting the biggest challenges in the communities around the universities (Naylor et al., 2017). As a QA_KPI, there should be journal(s) in the university to publish researched work. Journals should be based in departments and faculties of the university. The universities through journals can send out their new findings to communities for reading and implementation. The university journals to be vibrant, they should be geared towards producing quality research as guided by the 
university research policies and procedures (Carra, Loucksb, \& Bloschla, 2018; Martenssona et al., 2016; Panda \& Gupta, 2014). It might also be imperative for the university to have high ranking journals such as journals well ranked by ISI for the staff to publish their work. If the university does not have them, it should set standards that would make the university journals attain that level of proficiency in terms of rankings. It might not be possible for universities to publish their results in high impact factor journals but they should be able to disseminate their research findings through conferences. Having conferences and their frequency can greatly reflect the quality and quantity of research conducted at the university.

World class universities have either defined themselves as either research universities or teaching universities. The quality assurance key performance indicators in terms of research for universities should be directed towards the big vision of the university as either teaching or research universities (Jacob, Xiong \& Ye, 2015; Tremblay, Lalancette \& Roseveare, 2012). Quality assurance key performance indicators in terms of research for research universities are higher than those of teaching universities (Fitzgerald et al., 2016). Universities should be in the know of which standards as regards research they need as per the nature of the university. Either being a research or teaching university might largely depend on the quality of staff a university has to undertake research. Quality research in a university is based on QA_KPIs and the quality of senior research staff a university has in the various departments. A university with professors is likely to do more quality research than the university that does not have them. Key performance indicators in research should be able to bring about visibility of a university undertaking the research. Visibility of the university is as a result of the university increasing the volumes of research and publications in a particular period of time (Penfield et al., 2014). The more research and publications a university has in a given period of time makes it more visible and felt in the different academic arena and parts of the world. This is realized when large volumes of research are published in high impact factor journals (Tennant et al., 2016).

A university undertaking research should be able to attract research grants and also compete for them in the areas in which it is excelling. Research grants waive a big burden from the university in terms of research funding (Hottenrott, 2011). Funders who want their research questions answered put funds in higher education institution research boxes for their research questions to be answered. Institutions that have very high QA_KPIs put it to the faculties and departments to compete and also attract big research funds. This also depends on the research projects done to be able to attract research grants (Noor-Ul-Amin, ND). As regards admissions, universities should admit students who merit programmes, that is, students who have the required qualifications or grades. These students should measure to the standards of undertaking graduate research. Adequate admission of students should be done based on the competitiveness of the students (Stanford Centre for Opportunity Policy in Education, 2013). Students with the highest grades/ qualifications should be considered for postgraduate programme, and also for research. There should be an appropriate curriculum in place and strategies to review the curriculum. A curriculum offers a road map to have appropriate research and quality assurance measures (O’Neill, 2015). This supports the types of research to be 
done, quality of research, research and its projected impact to the community. The measures put in place would help in monitoring of the quality assurance systems and to have appropriate research QA_KPIs that would uplift the ranking of the university. With the relevant QA_KPIs, there should be in place quality assessment methods to assess the research conducted in higher education institutions (Jacob, 2015; O'Neil, 2015).

As an aspect of quality assurance universities should have qualified staff to undertake research and also train students admitted on the programmes. The academic staff would be those with the requisite qualification and should measure to the required standards. The staff employed by universities to do research should have opportunities for staff development to improve on their research skills. This would help the staff to improve on their knowledge and skills as regards training students (Henard \& Roseveare, 2012; Jacob, 2015). Training in new skills would bring about the adjustment in research skills of the staff which would be observed in the research output. In strengthening QA_KPIs, the university should provide adequate reading materials for students and staff undertaking research. Quality institutions of higher learning that have also the vision to advance in research should be able to attract international and reputable scholars in various fields, provide long-life learning, and create endowments to generate money for research activities (Henard \& Roseveare, 2012; Yang, Schneller \& Roche, 2015). Universities should be able to benchmark good practices from other universities, be able to facilitate students and staff mobility, and have networks and collaborations among other universities (Odongo, 2017; Williams, Kear \& Rosewell, 2015). Universities should train staff in quality assurance matters and also define their internal quality assurance standards. in the same vain they should establish processes of implementing KPIs as well as improving on the existing programmes and approval of new ones. According to previous studies done on key performance indicators none have been focused on the Islamic University in Uganda. Therefore, the purpose of this study was to analyse quality assurance key performance indicators in Ugandan universities taking a case study of the Islamic University in Uganda.

\section{Objectives of the Study}

(i) To find out the role of quality assurance key performance indicators in research at Islamic University in Uganda.

(ii) To examine the differences in staff perceptions on quality assurance key performance indicators in research at Islamic University in Uganda.

(iii) To examine the relationship between quality assurance key performance indicators variables used in maintaining quality in research at Islamic University in Uganda.

\section{METHOD}

\section{Design of the study}

This study was carried out using quantitative approaches considering cross sectional survey design to achieve the objectives of the study. The study was conducted at the Islamic University in Uganda with a focus on analysing the quality assurance key performance indicators in research undertaken at the University. The study considered a 
population of 465 staff in 2 campuses of Islamic University in Uganda. A total number of 200 questionnaires were distributed by hand to a sample of the staff in the two campuses. However, 180 questionnaires were returned fully filled and were analysed to get results for the study.

\section{Sample}

Using stratified and random sampling methods, a sample of 200 staff both academic and non-academic; 130 academic and 70 non-academic, and 138 males and 62 females was selected to participate in the study. During the survey, the staff were also instructed to give information on their qualifications (professor, associate professor, senior lecturer, lecturer, assistant lecturer, and teaching assistants), campus (Kampala campus and main campus), gender (males or female), category (administrator or academic), and classification (arts/ sciences).

\section{Instrument}

A 50 item quality assurance key performance indicator (QA_KPI) Questionnaire was developed to collect data for the study. The 50 item questionnaire had 10 dimensions each with 5 self-reported statements that required the staff to rate. The respondents were asked to testify how they were in agreement with the statements in the questionnaire. The 5-point likert scale which was used in the questionnaire ranged from strongly disagree, disagree, neutral, agree to strongly agree. The validity index (.883) and reliability coefficient (.801) measured by the Cronbach's alpha were conducted to determine the adequateness of the instrument. From the obtained results, it was discovered that the instrument was adequate to collect the data for the study.

\section{Data collection}

The researcher employed research assistants to collect data from the targeted participants for the study. Research assistants distributed questionnaires and also collected them from the participants of the study. The collection of the data was done in one month. The questionnaires received from the participants were sorted to find out whether all the returned questionnaires were fully filled before the data entry and analysis were done.

\section{Data analysis}

The study adopted both descriptive and inferential statistics to analyse and also interpret the results for the study. The data collected was analysed using descriptive analysis, factorial ANOVA, exploratory factor analysis, and simple regression to respond to the objectives of the study. The study used descriptive statistics to describe the primary data while the factorial ANOVA analyses were used to highlight the mean differences among the university staff perceptions on the role of QA_KPIs in research at the university level. Exploratory factor analysis used Kaiser-Meyer-Olkin (KMO) to measure the sample adequacy, the Bartlett test of sphericity, varimax rotational method, factor loadings and percentages of variances to measure the factor structure of the data generated. The relationships between variables were determined by the correlation coefficients of the simple regression analysis. 


\section{FINDINGS}

Role of quality assurance key performance indicators in controlling the quality of research

In the analysis of the role of quality assurance key performance indicators in research, the staff was asked to respond to whether QA_KPIs have a role in controlling the quality of research at the Islamic University in Uganda. From the results obtained, it was revealed that the majority of the staff were in agreement that QA_KPIs had a role in controlling the quality of research at the Islamic University in Uganda (IUIU). It is noted from Table 1 that $118(65.6 \%)$ of the staff agreed while $36(20 \%)$ strongly agreed that key performance indicators have a role in controlling the quality of research at University (IUIU). Only $18(10 \%)$ were neutral, $8(4.4 \%)$ disagreed and none strongly disagreed on the role played by quality assurance key performance indicators in controlling the quality of research at the Islamic University in Uganda.

Table 1

Frequencies for the role of quality assurance key performance indicators in research at IUIU $(\mathrm{N}=180)$

\begin{tabular}{llllc}
\multicolumn{1}{c}{ Scale value } & \multicolumn{1}{c}{ Scale } & $\mathrm{f}$ & $\%$ & $\mathrm{SD}$ \\
\hline $1.00-1.90$ & Strongly Disagree & 0 & 0.00 & 0 \\
\hline $2.00-2.90$ & Disagree & 8 & 4.4 & .36 \\
\hline $3.00-3.90$ & Neutral & 18 & 10.0 & .40 \\
\hline $4.00-4.90$ & Agree & 118 & 65.6 & .35 \\
\hline $5.00-5.90$ & Strongly Agree & 36 & 20.0 & .38 \\
\hline
\end{tabular}

$\mathrm{F}=$ frequency, $\%=$ percentage

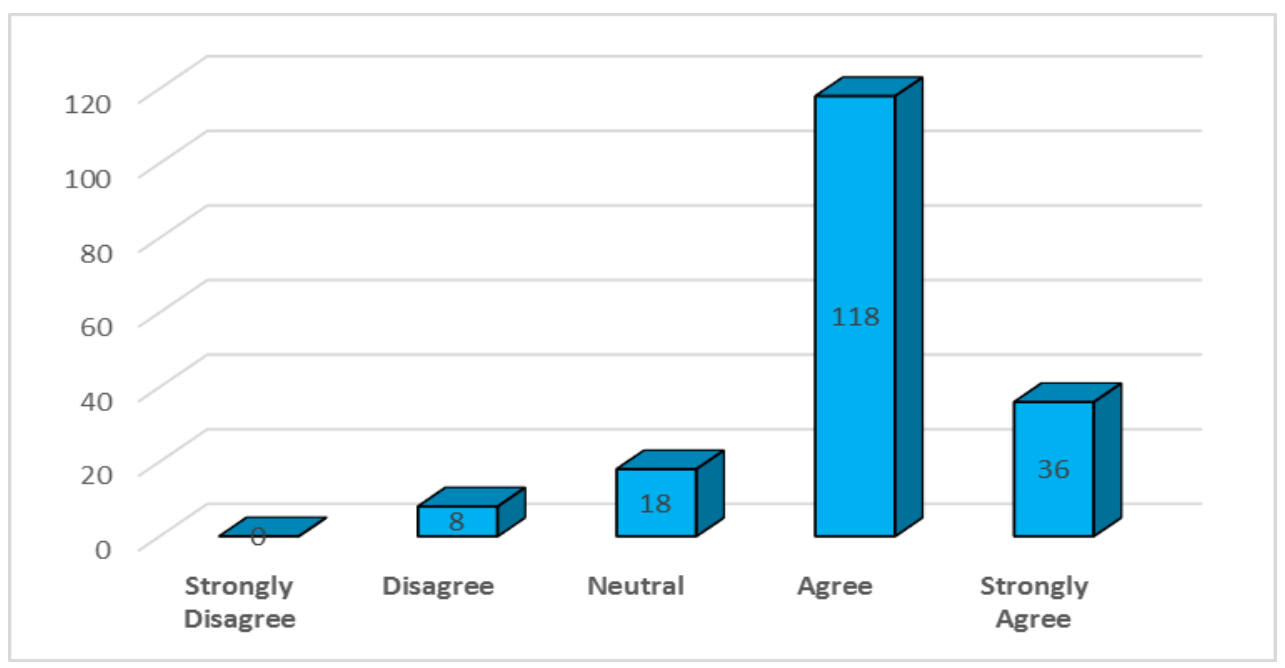

Figure 2

Agreement with the role of Key Performance Indicators in controlling quality in research 
In an analysis of the differences in perceptions of staff about the role of QA_KPIs in controlling quality in research at the Islamic University in Uganda, a factorial ANOVA was conducted to examine the differences among the different groups of staff under study. The factorial ANOVA was conducted on the category of staff (administrative or academic staff), gender, qualification, campus, and classification (science or arts). According to the results in Table 2, there was no statistically significant difference in perceptions of staff as regards quality assurance key performance indicators and quality of research in terms of the category of staff, gender, campus, and their classification. The results revealed that there was a statistically significant difference in perceptions of staff as regards the role of QA_KPIs in respect to their qualifications (partial eta squared, $\left.\eta^{2}=.241\right)$. Results from factorial ANOVA indicate that staff with lower qualification has poor perceptions about the role of key performance indicators on the quality of research at the University (IUIU). In other words, factorial ANOVA results as regards to qualification differ from others in relation to the category, gender, campus and classification of the staff (see Table 2).

Differences in staff perceptions on quality assurance key performance indicators adopted in research

Table 2

Factorial ANOVA for quality assurance key performance indicators in research

\begin{tabular}{lllllll}
\hline Variable(s) & $\begin{array}{l}\text { Sum of } \\
\text { Squares }\end{array}$ & df & $\begin{array}{l}\text { Mean } \\
\text { Square }\end{array}$ & F & Sig & $\begin{array}{l}\text { Partial Eta } \\
\text { Squared }\left(\eta^{2}\right)\end{array}$ \\
\hline $\begin{array}{l}\text { Category (Admin/ } \\
\text { Academic) }\end{array}$ & .187 & 1 & .165 & .788 & .325 & .006 \\
\hline Gender & .784 & 1 & .124 & 3.798 & .263 & .011 \\
\hline Qualification & 8.231 & 5 & 1.797 & 8.536 & .011 & .241 \\
\hline Campus & .362 & 3 & .362 & 1.360 & .121 & .013 \\
\hline $\begin{array}{l}\text { Classification (Science/ } \\
\text { Arts) }\end{array}$ & .123 & 1 & .124 & .589 & .348 & .009 \\
\hline Error & 29.881 & 141 & .186 & & & \\
\hline
\end{tabular}

In an interaction between qualification on quality of research, a statistically significant difference is observed $\left(F(5,180)=3.798, p<.011, \eta^{2}=.241\right)$. This means that the difference in the quality of research is brought about by the qualification of staff. From the results of partial eta squared $\left(\eta^{2}\right)$, it is noted that $24.1 \%$ of the variance in the quality of research is explained by qualification of the staff who undertake or supervise research at the University. In a descriptive rating, the variables of quality assurance key performance indicators in research using exploratory factor analysis two factors were generated as seen in Table 3 . 
Table 3

A factor structure of the quality assurance key performance indicators in research

\begin{tabular}{llcc}
\hline & \multicolumn{1}{c}{ Item(s) } & \multicolumn{2}{c}{ Factor Loading } \\
\cline { 3 - 4 } & & F1 & F2 \\
\hline 1. & Enrolment of students at the University & .88 & \\
\hline 2. & Funding of research activities at the University & .81 & \\
\hline 3. & Research facilities available at the University & .79 & \\
\hline 4. & $\begin{array}{l}\text { Faculties/ departments research scholarly activities at the } \\
\text { University }\end{array}$ & .78 & \\
\hline 5. & Staff to conduct/ supervise research at the University & .75 & \\
\hline 6. & Students' success in conducting research at the University & .70 & .86 \\
\hline 7. & Publishing researched work & & .78 \\
\hline 8. & Patenting ideas got out of research & & .73 \\
\hline 9. & Making of prototypes got out of research & .70 \\
\hline 10. & Making products out of research & & \\
\hline
\end{tabular}

Note: F1 = Key Performance Indicator (inputs), F2 = Performance of Key Performance Indicators (output)

Exploratory Factor Analysis (EFA) with varimax rotation was used to determine the number of factors in the Quality Assurance Key Performance Indicator questionnaire. From the EFA results, the Keyser-Meyer-Olkin (KMO) was .878 while the Bartlett's chi-square was an approximation of 442.16 with $\mathrm{p}=.000$. The results of the KMO which are close to 1.00 indicate that the correlation is compact enough to produce distinct factors as seen in Table 3. From the results of exploratory factor analysis, it has been observed that the components of the questionnaire are divided into two categories; (a) key performance indicator (input), and (b) key performance indicators (output). The key performance indicators (input) are those that are invested in or manipulated during research undertaken while key performance indicators (output) are those that are expected to be observed after the research has been conducted. The variables in QA_KPI questionnaire were correlated and results are revealed in Table 4.

\section{Relationship between quality assurance key performance indicators variables}

\section{Correlation Coefficient Test}

Before the correlation analysis was conducted, descriptive statistical analyses were conducted to study the cases of each cell and also to confirm whether the data analysed were normally distributed. The descriptive statistics revealed the adequateness of the sample taken into consideration for the study. The study tested for normality and linearity of the data. Using the Kolmogorov-Smirnov and Shapiro-Wilk tests, it was confirmed that the data met the assumption of normality. The fitness of the data made it suitable to be tested on the hypotheses of the study. In understanding the correlation between the variables under study, simple regression using Spearman Correlation values as seen in Table 4 highlight the association between quality assurance key performance indicators and quality of research at the Islamic University in Uganda. 
Table 4

Correlations between predictor and outcome variables

\begin{tabular}{|c|c|c|c|c|c|c|c|c|c|c|}
\hline & 1 & 2 & 3 & 4 & 5 & 6 & 7 & 8 & 9 & 10 \\
\hline 1 & - & & & & & & & & & \\
\hline 2 & $.48 *$ & - & & & & & & & & \\
\hline 3 & .16 & $.78 * * *$ & - & & & & & & & \\
\hline 4 & $.58 * *$ & $.68 * *$ & $.69 * *$ & - & & & & & & \\
\hline 5 & $.28 *$ & $.60 * *$ & $.48 *$ & $.48 *$ & - & & & & & \\
\hline 6 & .13 & $.75 * *$ & $.58 * *$ & $.55 * *$ & $.66^{* *}$ & - & & & & \\
\hline 7 & $.44 *$ & $.70 * * *$ & $.74 * * *$ & $.50 * *$ & $.60 * *$ & $.46^{*}$ & - & & & \\
\hline 8 & $.21 *$ & $.66 * *$ & $.43 *$ & $.55 * *$ & $.56 * *$ & $.51 * *$ & $.48 *$ & - & & \\
\hline 9 & .09 & $.45 * *$ & $.38 *$ & $.48 *$ & $.43^{*}$ & $.36^{*}$ & .19 & .10 & - & \\
\hline 10 & .11 & $.80 * * *$ & $.51 *$ & $.58 * *$ & $.65 * *$ & $.60 *$ & .17 & $26^{*}$ & .12 & - \\
\hline
\end{tabular}

The correlations analysis between quality assurance key performance indicators and quality of research at the Islamic University in Uganda was based on simple regression using on Spearman correlations. ${ }^{*} p<.05,{ }^{*} p<.01$ and $* * * p<.001$ were coded manually as seen in Table 4 while the labels are explained as follows; $1=$ Total enrolment, $2=$ funding, 3 = research facilities, $4=$ faculty scholarly activities, $5=$ quality of students and staff, $6=$ students' success in research, $7=$ publish, $8=$ patent, $9=$ prototype, and $10=$ products. According to Table 4 , it is observed that there is no significant relation revealed between enrolment and research facilities $(\mathrm{r}=.16, p>.05)$, students' success in research $(\mathrm{r}=.13, p>.05)$, prototype $(\mathrm{r}=.09, p>.05)$, and products $(\mathrm{r}=.11, p>.05)$. Also, according to Table 4, there is no significant relationship between publishing and prototype $(\mathrm{r}=.19, p>.05)$, and product $(\mathrm{r}=.17, p>.05)$. Other insignificant relationships existed between patent and prototype $(\mathrm{r}=.10, p>.05)$, and product $(\mathrm{r}=.12, p>.05)$. It can be noted from table 4 that most of the associations are significant.

\section{DISCUSSION}

The study has provided evidence on the relationship between quality assurance key performance indicators and quality of research in Ugandan Universities with the case study of the Islamic University in Uganda. From the results of the study, it has been discovered that staff differed in terms of perceptions as regards quality assurance key performance indicators from their counterparts in regard to the category, gender, campus and classification of the staff. Furthermore, it is noted that there is no significant relationship between enrolment and research facilities, students' success in research, prototype, and product. There is no significant relationship between publishing and prototype, and product. Other insignificant relationships were between patent and prototype, and products. According to the correlation results, insignificant relationships were observed in enrolment with facilities, students' success in research, prototypes and making products out of researched ideas. The insignificant relationships with the variables are due universities admitting students without facilities in place and putting much emphasis on students grades than research skills. 
There is always anticipation in universities that they might not be able to enrol students in the various fields, or win research grants, or assume that the money to set up the research facilities is part of the research grants they will win. Many universities today do not look at the quality of students they enrol on programmes but numbers that will raise money to fund their projected budgets (Betts, Hartman \& Oxholm, 2009). The existence of statistical insignificance between enrolment and students' success is largely on the quality of students enrolled on the various programmes within the University. As regards to publishing and other variables such as prototypes, patent and product, these are not common in universities today (Breschi, Lissoni \& Montobbio, 2005; Magnificus, 2016; Stephan, Gurmu, Sumell \& Black, 2007). In the research process, most universities stop at the publication as the final level in the research process. Many students and staff of universities undertake research but it is just left on shelves to collect 'dust' (Head, 2016). The statistical insignificance between enrolment, patenting and products got out of research, is dependent on the nature of research conducted within the universities. In most of the universities in Uganda, research is students based and requires students to only publish their results. This makes patents, prototypes and making products out of researched work not to be achieved (Gurjar, 2015; Yang \& Epstein, 2005).

\section{CONCLUSION AND RECOMMENDATION}

To improve research in universities in Uganda, there should be adequate recruitment or enrolment of students who merit university programs, and can also do research. Once competent students are enrolled into the various programmes, students will be retained onto the programmes and also graduate on time. In maintaining the quality of research there should be mechanisms to attract and retain outstanding staff. In attracting and retaining staff, there should be good faculties' salaries and benefits, staff satisfaction, endowed chairs and professorships, good faculty tenure, continuous human resource training and lowering staff turnover rate (Tack \& Patitu, 1992). There should be other measurable and attainable QA_KPIs such as setting up adequate facilities to support research, increase funding to research and its support activities, attract research grants and also compete for them (Wang, 2010). Universities should start journals in all departments to publish researched work, staff and students should publish in high profile journals, employ quality staff to undertake or guide others in conducting research, and increase on the volumes of research, publications, prototypes and products got through research. There should also be improvement in the university policies that guide research, publications, and innovations. There should be increased scholarly activities at the universities, institutions should provide adequate resources such as books, eresources, library, motivate staff and students to do research and also benchmark good research practices from other universities. There should also be patenting of all ideas got through research, make prototypes to conceptualize research ideas, make products from all research ideas and establish effective processes of implementing quality assurance key performance indicators. 


\section{REFERENCES}

Asian Pacific Economic Cooperation [APEC] (2011). Quality in Higher Education: Identifying, Developing and Sustaining Best Practices in the APEC Region. APEC Human Resource Development Working Group. Retrieved 09 ${ }^{\text {th }}$ September, 2018 from file://C:/Users/COMPAQ/Downloads/2011_hrd_quality_education.pdf.

Ballard, P. J. (2013). Measuring Performance Excellence: Key Performance Indicators for Institutions Accepted into the Academic Quality Improvement Program (AQIP). $\mathrm{PhD}$ Dissertation. Western Michigan University. Retrieved $04^{\text {th }}$ May, 2018 from https://scholarworks. wmich.edu/cgi/viewcontent.cgi? article $=1198 \&$ context=dissertation s.

Betts, K., Hartman, K., \& Oxholm, C. (2009). Re-examining \& Repositioning Higher Education: Twenty Economic and Demographic Factors Driving Online and Blended Program Enrolments. Journal of Asynchronous Learning Networks, 13(4), 3-23. http://www.anitacrawley.net/Resources/Articles/Betts.pdf.

Breschi, S., Lissoni, F., \& Montobbio, F. (2005). From publishing to patenting: Do productive scientists turn into academic inventors? 2nd ZEW Conference on the Economics of Innovation and Patenting Mannheim, September 19-20 2005. Retrieved $08^{\text {th }} \quad$ May, 2018 from http://ftp.zew.de/pub/zewdocs/veranstaltungen/inno_patenting_conf/BreschiLissoniMontobbio\%20.pdf.

Brockerhoff, L., Huisman, J., \& Laufer, M. (2015). Quality Higher Education. A Literature Review. Centre for Higher Education Governance. Belgium. Retrieved 12 April, 2018 from file:///C:/Users/HP/Desktop/Quality-in-Higher-Education-A-literaturereview-1.7.pdf.

Carra, G., Loucksb, D. P., \& Blöschla, G. (2018). Gaining Insight into Interdisciplinary Research and Education Programmes: A framework for evaluation, Research Policy, 47(1), 35-48. https://doi.org/10.1016/j.respol.2017.09.010.

Coe, R., Aloisi, C., Higgins, S., \& Elliot, L (2014). What makes great teaching? Review of the underpinning research. Retrieved 13 March, 2018 from www.suttontrust.com/wpcontent/uploads/2014/10/What-makes-great-teaching-FINAL-4.11.14-1.pdf.

Council on Higher Education [CHE] (2016). South African higher education reviewed: Two decades of democracy. Council on Higher Education, Pretoria, South Africa. ISBN: 978-0-9946785-4-3.

Eckerson, W. W. (2009). Performance Management Strategies: How to Create and Deploy Effective Metrics. Retrieved $05^{\text {th }}$ April, 2018 from https://www.microstrategy.com/Strategy/media/downloads/whitepapers/TDWI_Performance-Management-Strategies.pdf. 
Elassy, N. (2015). The Concepts of Quality, Quality Assurance and Quality Enhancement. Quality Assurance in Education, 23(3), 250- 261. Retrieved $12^{\text {th }}$ January, 2018 from https://doi.org/10.1108/QAE-11-2012-0046.

ESG. (2015). Standards and Guidelines for Quality Assurance in the European Higher Education Area (ESG). European Association for Quality Assurance in Higher Education. Brussels: EURASHE. Retrieved 28 ${ }^{\text {th }}$ April, 2018 from https://enqa.eu/wpcontent/uploads/2015/11/ESG_2015.pdf.

Fitzgerald, H. E., Bruns, K., Sonka, S. T., Furco, A., \& Swanson, L. (2016). The Centrality of Engagement in Higher Education: Reflections and Future Directions. Journal of Higher Education Outreach and Engagement, 20(1), 245-254. Retrieved $10^{\text {th }}$ July, 2018 from file://C:/Users/COMPAQ/Downloads/1609-3595-1SM\%20(1).pdf.

Gueorguiev, T. K. (2017). Social Responsibility as a Key Performance Indicator for the Quality of Educational Processes. Journal of Thermal Engineering, 1(1), 35-41. https://doi.org/10.18186/jte.93766.

Gurjar, T. P. (2015). Effects of a Structured Prototyping Strategy on Capstone Design Projects. $122^{\text {nd }}$ ASSE Annual Conference and Exposition, June $14-17$, 2015, Seattle, WA. $\quad$ Retrieved $30^{\text {th }} \quad$ May, 2018 from https://repositories.lib.utexas.edu/bitstream/handle/2152/31974/GURJAR-THESIS2015.pdf? sequence $=1 \&$ isAllowed $=y$.

Harvey, L., \& Green, D. (1993). Defining Quality. Assessment \& Evaluation in Higher Education, 18(1), 9-34. https://doi.org/10.1080/0260293930180102.

Head, A. J. (2016). Planning and Designing Academic Library Learning Spaces: Expert Perspectives of Architects, Librarians, and Library Consultants. Project Information Literacy. Retrieved $13^{\text {th }}$ February, 2018 from http://projectinfolit.org.

Henard, F., \& Leprince-Ringuet, S. (2008). The path to quality teaching in higher education: programme Institutional Management for Higher Education (IMHE). Retrieved 24 ${ }^{\text {th }}$ March, 2018 from http://www.oecd.org/education/imhe/44150246.pdf.

Henard, F., \& Roseveare, D. (2012). Fostering Quality Teaching in Higher Education: Policies and Practices: An IMHE Guide for Higher Education Institutions. Directorate for Education of the OECD. Retrieved $09^{\text {th }}$ September, 2018 from https://www.oecd.org/education/imhe/QT\%20policies\%20and\%20practices.pdf.

Hennessy, S., Onguko, B., Harrison, D., Ang’ondi, E. K., Namalefe, S., Naseem, A., \& Wamakote, L. (2010). Developing the Use of Information and Communication Technology to Enhance Teaching and Learning in East African Schools: Review of the Literature. Centre for Commonwealth Education \& Aga Khan University Institute for Educational Development - Eastern Africa Research Report No. 1. 
Hottenrott, H. (2011). The Role of Research Orientation for Attracting Competitive Research Funding. $\quad$ Retrieved $11^{\text {th }} \quad$ April, 2018 from https://core.ac.uk/download/pdf/6289940.pdf.

Inter-University Council for East Africa (IUCEA) (2010). A road map to quality. Hand book for quality assurance in higher education. Volume 2: Guidelines for external assessment at programme level. Retrieved 12 $2^{\text {th }}$ April, 2018 from http://www.must.ac.ug/downloads/Quality\%20Assurance\%20-

$\% 20$ Handbook\%20Vol\%202.pdf.

Inter-University Council for East Africa (IUCEA) (ND). The need to establish a regional system of accreditation of higher education institutions and programmes in East Africa. $\quad$ Retrieved $12^{\text {th }} \quad$ April, 2018 from file://C:/Users/COMPAQ/Downloads/IUCEA-regional_accreditation.pdf.

ISESCO (2016). The Role of Higher Education in the Development of Science and Technology for a Prosperous Future: Key Performance Indicators for Universities in Islamic Countries, ICMHESR-6/2012/2.4. Sixth Islamic Conference. Retrieved $22^{\text {nd }}$ December, 2018 from https://www.isesco.org.ma/wp-content/uploads/2016/02/6cimc2.4.pdf.

IUCEA (September, 2011). Rolling strategic plan. IUCEA. Retrieved $07^{\text {th }}$ September, 2018 from https://www.idea-phd.net/images/doc-pdf/IUCEA_StratPlan_2011_2016.pdf.

Jacob, J. W., Xiong, W., \& Ye, H. (2015). Professional development programmes at world-class universities. Palgrave Communications, $1 \quad$ - 27. https://doi.org/10.1057/palcomms.2015.2.

Kane, G. C., Palmer, D., Phillips, A. N., Kiron, D., \& Buckley, N. (2016). Digitally savvy executives are already aligning their people, processes, and culture to achieve their organizations' long-term digital success. Retrieved 10 April, 2018 from https://sloanreview.mit.edu/projects/aligning-for-digital-future/

Karen, E. H. (2012). A practical guide to strategic planning in higher education. Society for College and University Planning. Retrieved $7^{\text {th }}$ June, 2018 from www.scup.org.

Kis. V. (2005). Quality Assurance in Tertiary Education: Current Practices in OECD Countries and a Literature Review on Potential Effects. Tertiary Review, OECD Thematic Review of Tertiary Education. Retrieved 20 ${ }^{\text {th }}$ January, 2018 from https://www.oecd.org/education/skills-beyond-school/38006910.pdf.

Kwadwo, A. G., \& Addaney, M. (2016). Managing Quality Assurance in Higher Education: The Case of the University of Energy and Natural Resources, Ghana. Journal of Education and Practice, 7(22), 41 - 46. Retrieved 10 $10^{\text {th }}$ June, 2018 from https://files.eric.ed.gov/fulltext/EJ1112941.pdf. 
Lee, D. J., Park, S. J., \& Kim, K. T. (2013). A Development of Key Performance Indicators for the Public R\&D of Energy Technology using Balanced Scorecard Approach. Proceedings of the World Congress on Engineering and Computer Science, WCECS 2013, 23-25 October, 2013. Retrieved 23 ${ }^{\text {rd }}$ March, 2018 from https://pdfs.semanticscholar.org/38f5/b11b0e67ea6db5e63ce3260ff64d16da7d06.pdf.

Magnificus, R. (2016). Patents and trademarks: Motivations, antecedents, and value in industrialized and emerging markets. Master's Thesis, Erasmus University Rotterdam, Netherlands.

Manghani, K. (2011). Quality Assurance: Importance of Systems and Standard Operating Procedures. Perspectives in Clinical Research, 2(1), 34-37. https://doi.org/10.4103/2229-3485.76288.

Martenssona, P., Fors, Ub., Wallinc, S. B., Zander, U., \& Nilssone, G. H. (2016). Evaluating research: A multidisciplinary approach to assessing research practice and quality. Research Policy, 45, 593-603. https://doi.org/10.1016/j.respol.2015.11.009.

Masayna, V., Koronios, A., \& Gendron, M (ND). Data quality and KPIs: A link to be established. The 2nd World Congress on Engineering Asset Management (EAM) and the 4th International Conference on Condition Monitoring, 1377-1386.

Matovu, M. (2017). The State of Internal Quality Assurance Systems in Ugandan Universities Issues, Opportunities and Challenges. European Journal of Education Studies, 3(8), 703-728. Retrieved 23 ${ }^{\text {rd }}$ June, 2018 from https://oapub.org/edu/index.php/ejes/article/view/983.

Mbabazi, P. B. (2013). Quality in Learning in Rwandan Higher Education Different stakeholders' perceptions of students' learning and employability. Masters' Dissertation. Linköping University, Department of Behavioural Sciences and Learning, Linköping University. Retrieved $02^{\text {nd }}$ May, 2018 from http://liu.divaportal.org/smash/get/diva2:602176/FULLTEXT01.pdf.

Meier, H., Lagemann, H., Morlock, F., \& Rathmann, C. (2013). Key performance indicators for assessing the planning and delivery of industrial services. 2nd International Through-life Engineering Services Conference. Elsevier Procedia CIRP, 11, 99 - 104. https://doi.org/10.1016/j.procir.2013.07.056.

Michaela, M. (2018). Internal Quality Assurance: Enhancing higher education quality and graduate employability: New trends in higher education. UNESCO Publishing. $\begin{array}{llll}\text { Retrieved } & 08^{\text {th }} & \text { September, } & 2018\end{array}$ http://unesdoc.unesco.org/images/0026/002613/261356e.pdf.

National Council for Higher Education (NCHE) (2009). Information and communication technology Plan. NCHE, Kampala Uganda. 
National Council for Higher Education (NCHE) (2011). State of higher education and training in Uganda: A report on higher education delivery and institution. NCHE, Kampala Uganda.

Naylor, D., Birgeneau, R., Crago, M., Lazaridis, M., Malacrida, C., McDonald, A., Piper, M., Quirion, R., \& Wilson, A., (2017). Investing in Canada's Future: Strengthening the Foundations of Canadian Research. Canada's Fundamental Science Review. $\quad$ Retrieved $\quad 14^{\text {th }} \quad$ April, 2018 from http://www.sciencereview.ca/eic/site/059.nsf/vwapj/sciencereview_april2017.pdf/\$file/s ciencereview_april2017.pdf.

Nkunya, M. H. H. (2011). DIES conference on strengthening universities, enhancing capacities in higher education management for development. 28 - 29 November, Bonn, Germany.

Nkunya, M. H. H., \& Joseph, C. C. (nd). Developing a Regional quality assurance system for higher education in East Africa: Progress and experiences. Inter-University Council for East Africa (IUCEA).

Noor-Ul-Amin, S. (ND). An Effective use of ICT for Education and Learning by Drawing on Worldwide Knowledge, Research, and Experience: ICT as a Change Agent for Education. A Literature Review. University of Kashmir. Retrieved 01 ${ }^{\text {st }}$ May, 2018 from http://www.nyu.edu/classes/keefer/waoe/amins.pdf.

O'Neill, G. (2015). Curriculum Design in Higher Education: Theory to Practice, Dublin: UCD Teaching \& Learning. ISBN 9781905254989. Retrieved $10^{\text {th }}$ April, 2018 from http://www.ucd.ie/t4cms/UCDTLP0068.pdf.

Odongo, R. (2017). Standards and Guidelines for Quality Assurance in Higher Education in Africa. 12th European Quality Assurance Forum hosted by the University of Latvia 23rd - 25th November 2017, Riga, Latvia.

Owino, G. C., Ogachi, O. I., \& Olel, M. A. (2011). Role of institutional managers in quality assurance: reflections on Kenya's university education. Australian Journal of Business and Management Research, 1(2), 115-124. Retrieved $07^{\text {th }}$ May, 2018 from http://www.ajbmr.com/articlepdf/ajbmr_v01n02_08.pdf.

Paintsil, R. (2016). Balancing Internal and External Quality Assurance Dynamics in Higher Education Institutions: A Case Study of University of Ghana. Master's Thesis. University of Oslo.

Panda. A., \& Gupta, R. K. (2014). Making Academic Research More Relevant: A few Suggestions. IIMB Management Review, 26, 156-169. https://doi.org/10.1016/j.iimb.2014.07.008.

Penfield, T., Baker, M. J., Scoble, R., \& Wykes, M. C. (2014). Assessment, Evaluations, and Definitions of Research Impact: A review. Research Evaluation, 23(1), 21-32. Retrieved 02 ${ }^{\text {nd }}$ January, 2018 from https://doi.org/10.1093/reseval/rvt021. 
Piela, J. (2017). Key performance indicator analysis and dashboard visualization in a logistics company. Master's Thesis, Lappeenranta University of Technology. Retrieved $10^{\text {th }} \quad$ June, 2018 from https://www.doria.fi/bitstream/handle/10024/147689/Master\%27s_Thesis_Piela_Joonat an.pdf? sequence $=1 \&$ isAllowed $=\mathrm{y}$.

Salilul, A. H., \& Shahadat, H. S. (2016). Determinants of Education Quality: What Makes Students' Perception Different? Open Review of Educational Research, 3(1), $52-$ 67. https://doi.org/10.1080/23265507.2016.1155167.

Sanga, P. L., \& Ahn, M. L. (2014). Challenges and Opportunities for Quality Assurance of Cross-Border Higher Education: The Case of East Africa. Journal of Emerging Trends in Educational Research and Policy Studies, 5(1), 126-132. Retrieved $24^{\text {th }}$ April, 2018 from https://pdfs.semanticscholar.org/70d2/6924d6773883116198896e62cc65199107b2.pdf.

Stanford Centre for Opportunity Policy in Education (2013). Criteria for High-Quality Assessment. Stanford Centre for Opportunity Policy in Education, Stanford University. Retrieved $25^{\text {th }} \quad$ April, 2018 from https://www.hewlett.org/wpcontent/uploads/2016/08/Criteria_for_High_Quality_Assessment_June_2013.pdf.

Stephan, P. E., Gurmu, S., Sumell, A. J., \& Black, G. (2007). Who's Patenting in the University? Evidence from the Survey of Doctorate Recipients. Economics of $\begin{array}{lllll}\text { Innovation } \quad \text { and New Technology } & \text { 16(2), }\end{array}$ https://doi.org/10.1080/10438590600982806.

Tack, M. W.; \& Patitu, C. L. (1992). Faculty Job Satisfaction: Women and Minorities in Peril. ASHE-ERIC Higher Education Report No. 4, 1992. Office of Educational Research and Improvement (ED), Washington, DC.

Tennant, J. O., Waldner, F., Jacques, D. C., Masuzzo, P., Collister, L. B., \& Hartgerink, C. H. J (2016). The Academic, Economic and Societal Impacts of Open Access: An Evidence-Based Review. Research Open for Science, 5, 623. https://doi.org/10.12688/f1000research.8460.3.

Tremblay, K., Lalancette, D., \& Roseveare, D. (2012). Assessment of Higher Education Learning Outcomes Feasibility Study Report: Volume 1 - Design and Implementation. Retrieved $09^{\text {th }}$ September, 2018 from http://www.oecd.org/education/skills-beyondschool/AHELOFSReportVolume1.pdf.

VanVught, F. A., \& Westerheijden, D. F. (1994). Towards a General Model of Quality Assessment in Higher Education. Higher Education, 28, 355-371. https://doi.org/10.1007/BF0138372.

Wang, X. (2010). Performance measurement in universities: Managerial perspective. Master's Thesis. University of Twente. Retrieved $05^{\text {th }}$ May, 2018 from https://essay.utwente.nl/60180/1/MA_thesis_X_Wang.pdf. 
Williams, J. (2016). Quality Assurance and Quality Enhancement: Is There a Relationship? Quality in Higher Education, 22(2), 97-102. https://doi.org/10.1080/13538322.2016.1227207.

Williams, K., Kear., \& Rosewell, J. (2015). Quality Assessment for E-learning: A Benchmarking Approach. Retrieved 19 $9^{\text {th }}$ February, 2018 from http://oro.open.ac.uk/34632/2/3D5D7C.pdf.

Yang, J., Schneller, C., \& Roche, S. (2015). The Role of Higher Education in Promoting Lifelong Learning. UNESCO Institute for Lifelong Learning, Feldbrunnenstrasse, Hamburg, Germany. Retrieved 28 ${ }^{\text {th }}$ December, 2017 from https://www.bvekennis.nl/Bibliotheek/15-0467.pdf.

Yang, M. C., \& Epstein, D. J. (2005). A Study of Prototypes, Design Activity, and $\begin{array}{llll}\text { Design Outcome. Design } & \text { Studies, }\end{array}$ https://doi.org/10.1016/j.destud.2005.04.005. 